\title{
PTEN/pAkt/p53 signaling pathway correlates with the radioresponse of non-small cell lung cancer
}

\author{
IL LAE JUNG, HYO JIN KANG, KUG CHAN KIM and IN GYU KIM \\ Department of Radiation Biology, Environmental Radiation Research Group, \\ Korea Atomic Energy Research Institute, Yuseong, Daejeon 305-600, Korea
}

Received October 12, 2009; Accepted December 16, 2009

DOI: $10.3892 /$ ijmm_00000372

\begin{abstract}
The sensitivity or resistance of cancer cells and normal tissues to ionizing radiation plays an important role in the clinical setting of lung cancer treatment. However, to date the exact molecular mechanisms of intrinsic radiosensitivity have not been well explained. In this study, we compared the radiosensitivity or radioresistance in two non-small cell lung cancers (NSCLCs), H460 and A549, and investigated the signaling pathways that confer radioresistance. H460 cells showed a significant $\mathrm{G}_{2} / \mathrm{M}$ arrest after $12 \mathrm{~h}$ of irradiation (5 Gy), reaching $60 \%$ of $\mathrm{G}_{2} / \mathrm{M}$ phase arrest. A549 cells also showed a significant $\mathrm{G}_{2} / \mathrm{M}$ arrest after $12 \mathrm{~h}$ of exposure; however, this arrest completely disappeared after $24 \mathrm{~h}$ of exposure. A549 has higher methylated CpG sites in PTEN, which is correlated with tumor radioresistance in some cancer cells, than H460 cells, and the average of the extent of the methylation was 4.3 times higher in A549 cells than in H460 cells. As a result, PTEN expression was lower in A549 than in H460. Conducting Western blot analysis, we found that PTEN acted as a negative regulator for pAkt, and the pAkt acted as a negative regulator for p53 expression. According to the above results, we concluded that the radiosensitivity shown in H460 cells may be due to the higher expression of PTEN through p53 signaling pathway.
\end{abstract}

\section{Introduction}

Of the numerous public health problems, lung cancer is one of the leading causes of death throughout the world (1-3). Patients with lung cancer have a $<15 \%$ rate of survival over 5 years with current therapeutic modalities; this statistic has changed only minimally in the last 25 years, underscoring the need for new therapeutic strategies. Thus, understanding the molecular mechanisms involved in the pathogenesis of lung cancer may

Correspondence to: Dr In Gyu Kim, Department of Radiation Biology, Environmental Radiation Research Group, Korea Atomic Energy Research Institute, Yuseong, Daejeon 305-600, Korea E-mail: igkim@kaeri.re.kr

Key words: methylation, non-small cell lung cancer, p53, pAkt, PTEN, radioresponse provide greater opportunities to improve therapeutic methods for this fatal disease $(4,5)$.

For almost 100 years, radiotherapy with ionizing radiation, either alone or in combination with chemotherapy, has been widely used, but radioresistance of some human tumors to ionizing radiation and injury to normal tissues are the primary disadvantages that have an impact on the curative effect of clinical radiotherapy (6). The sensitivity or resistance of cancer cells and normal tissues to ionizing radiation plays an important role in the clinical setting. However, to date the exact molecular mechanisms of intrinsic radiosensitivity have not been clarified. Numerous oncogenes and antioncogenes (tumor-suppressor genes) seem to be responsible for the intrinsic radiosensitivity of a tumor and their crosstalk plays an important role (6). Oncogenes, such as ras, myc, raf, cox-2, PTEN, PI3K/Akt, and mutated p53, are correlated with tumor radioresistance in many cells, whereas the most important tumor-suppressor gene, wild-type $p 53$, is correlated with tumor radiosensitivity (7-27).

Although chemotherapy is often used to treat patients with non-small cell lung cancer (NSCLC), it offers only a small improvement and cell lines derived from these tumors exhibit an intrinsic resistance to both chemotherapy and radiotherapy in vitro compared with other types of cancer cells (28). In addition, great differences in response exist between NSCLCs with the same histology (29). Therefore, it is necessary to determine appropriate strategies to improve treatment efficacy, especially with respect to a curative approach in radiotherapy $(30,31)$. In this study, we compared the radiosensitivity or radioresistance in two NSCLCs, H460 and A549, which have a functional p53, and investigated the signaling pathways that confer radioresistance.

\section{Materials and methods}

Cell culture and irradiation. All NSCLC cell lines used in the study were obtained from American Type Culture Collection (ATCC; Manassas, VA, USA) and were grown in RPMI1640 medium supplemented with $10 \%$ fetal bovine serum (FBS; Hyclone Laboratories, Waltham, MA, USA) and penicillin/streptomycin. Cells were incubated at $37^{\circ} \mathrm{C}$ in a humidified atmosphere with $95 \%$ air $/ 5 \% \mathrm{CO}_{2}$. Cells were inoculated at a density of $1 \times 10^{5}$ cells in a T-25 flask and incubated for 1 day, followed by irradiation with a dose of 10 Gy using a ${ }^{60} \mathrm{Co} \gamma$-ray at a dose rate of $0.2 \mathrm{~Gy} / \mathrm{min}$. 
cDNA synthesis and PCR amplification. Total RNA was isolated from $\mathrm{H} 460$ and A549 using the Qiagen RNA extraction kit (Qiagen, Valencia, CA, USA). To generate first-strand cDNA from the total RNA $(1 \mu \mathrm{g})$ using oligo dT, a cDNA synthesis kit (MBI Fermentas, Burlington, ON, Canada) was used. Resultant cDNAs served as templates for PCR amplification with forward and reverse primers as follows: PTEN-F, 5'-ACGGGAAGACAAGTTCATGTAC; PTEN-R, 5'-ACAGTAGAGGAGCCGTCAAA; ß-actin-F, 5'-ATGTGCAAGGCCCGCTTCG; ß-actin-R, 5'-TTAAT GTCACGCACGATTTCC. For amplifying GC-rich PTEN template high, we added a specific buffer, i-GC capture solution (Intron Biotechnology, Korea), to the PCR mixture. The PCR conditions for PTEN were: denaturing at $95^{\circ} \mathrm{C}$ for $30 \mathrm{sec}$, followed by 35 cycles at $95^{\circ} \mathrm{C}$ for $30 \mathrm{sec}$, at $58^{\circ} \mathrm{C}$ for $30 \mathrm{sec}$, at $72^{\circ} \mathrm{C}$ for $1 \mathrm{~min}$, and a final extension at $72^{\circ} \mathrm{C}$ for $5 \mathrm{~min}$. The amplified PCR products were analyzed by agarose gel (1\%) electrophoresis, and photographed under UV light.

Western blot analysis. Anti-p53 and anti-PTEN antibodies for Western blot analysis were purchased from Santa Cruz Biotechnology (Santa Cruz, CA, USA) and Akt, phospho-Akt (pAkt), and $B$-actin were purchased from Cell Signaling Technology (Beverly, MA, USA). All reagents used in this study were reagent grade or better. Protein concentration was determined using a Lowry kit (Bio-Rad, Hercules, CA, USA). Equal amounts of protein were separated on 12\% SDS-PAGE and transferred to a nitrocellulose membrane (Hybond ECL; Amersham Pharmacia, Piscataway, NJ, USA). The blots were blocked for $2 \mathrm{~h}$ at room temperature with blocking buffer [10\% nonfat milk in PBS buffer containing 0.1\% Tween-20 (TBS)]. The membrane was incubated at room temperature for $1 \mathrm{~h}$ with specific antibodies. After washing with TBS, the membrane was incubated with a horseradish peroxidaselabeled secondary antibody and visualized using the Westzol enhanced chemiluminescence detection kit (Intron Biotechnology, Gyungki-do, Korea).

Flow cytometric detection. Irradiated and non-irradiated cells were collected, washed with PBS, and fixed with $70 \%$ ethanol at $4^{\circ} \mathrm{C}$ for $2 \mathrm{~h}$ in the dark. Fixed cells were washed with PBS and stained with propidium iodide $(50 \mu \mathrm{g} / \mathrm{ml})$. The DNA content was measured with a FACScan (EPICS XL, Beckman Coulter Counter, Fullerton, CA, USA). A minimum of 10,000 cells was counted for each sample. The percentage of cells in each cell phase was determined by Phoenix Multi-cycler Software (Phoenix Flow System, San Diego, CA, USA).

Sodium bisulfite modification. Bisulfite-modified genomic DNA (gDNA) was prepared using the EZ DNA MethylationGold kit (Zymo Research, Orange, CA, USA) according to the manufacturer's instructions. The bisulfite reaction was carried out on $400 \mathrm{ng}$ gDNA, the reaction volume was adjusted to $20 \mu 1$ with sterile water, and $130 \mu \mathrm{l} \mathrm{CT}$ conversion reagent was added. The sample tubes were placed in a thermal cycler (MJ Research, Waltham, MA, USA) and the following steps were performed: $10 \mathrm{~min}$ at $98^{\circ} \mathrm{C}$ and $2 \mathrm{~h} 30 \mathrm{~min}$ at $64^{\circ} \mathrm{C}$, and then stored at $4^{\circ} \mathrm{C}$. The resultant DNA was purified using reagent contained in EZ DNA Methylation-Gold kit (Zymo Research). The converted samples were added to a Zymo-Spin
$\mathrm{IC}^{\mathrm{TM}}$ column containing $600 \mu \mathrm{l}$ of the M-Binding buffer and mixed by inverting the column several times. The column was centrifuged at full speed for $30 \mathrm{sec}$ and the flow-through discarded. The column was washed by adding $200 \mu \mathrm{l}$ M-Wash buffer and centrifuged at full speed and then $200 \mu \mathrm{l}$ M-desulphonation buffer was added to the column and incubated at room temperature $\left(20-30^{\circ} \mathrm{C}\right)$ for $15-20 \mathrm{~min}$. After incubation, the column was centrifuged at full speed for $30 \mathrm{sec}$. The column was washed by adding $200 \mu \mathrm{l}$ M-Wash buffer and centrifuged at full speed (this step was repeated once more). The converted gDNA was eluted by adding $20 \mu \mathrm{l}$ M-Elution buffer into the column. DNA samples were finally stored at $-20^{\circ} \mathrm{C}$ until further use.

Pyrosequencing analysis. PCR reaction was carried out in a volume of $50 \mu 1$ with $\leq 20 \mathrm{ng}$ converted gDNA, $5 \mu 1$ 10X Taq buffer, 5 U Hot/Start Taq polymerase (Enzynomics, Daejeon, Korea), $4 \mu 1$ of each $2.5 \mathrm{mM}$ dNTP mixture, $2 \mu 1$ of $10 \mathrm{pmol} / \mu 1$ Primer-S, and $2 \mu 1$ of $10 \mathrm{pmol} / \mu 1$ biotinylated-Primer-As. The amplification was carried out according to the general guidelines suggested by pyrosequencing: denaturing at $95^{\circ} \mathrm{C}$ for $15 \mathrm{~min}$, followed by 45 cycles at $95^{\circ} \mathrm{C}$ for $40 \mathrm{sec}$, at $55^{\circ} \mathrm{C}$ for $40 \mathrm{sec}$, at $72^{\circ} \mathrm{C}$ for $40 \mathrm{sec}$, and a final extension at $72^{\circ} \mathrm{C}$ for $10 \mathrm{~min}$. PCR $(5 \mu \mathrm{l})$ was confirmed by electrophoresis in a $3 \%$ agarose gel and visualized by ethidium bromide staining. A ssDNA template was prepared from 20-25 $\mu$ l biotinylated PCR product using streptavidin Sepharose ${ }^{\circledR}$ HP beads (Amersham Biosciences, Uppsala, Sweden) following the PSQ 96 sample preparation guide using multichannel pipettes. Then $15 \mathrm{pmol}$ of the respective sequencing primer set was added for analysis. Sequencing was performed on a PyroMark ID system with the Pyro Gold reagents kit (Biotage, Charlottesville, VA, USA) according to the manufacturer's instructions without further optimization. The methylation percentage was calculated by the average of the degree of methylation at 5 or $6 \mathrm{CpG}$ sites formulated in pyrosequencing.

Microscopy and analysis of cell survival fraction. To compare the differences of morphology between H460 and A549, cells were visualized by light microscopy (Leica Microsystems, Westchester, IL, USA). Images were captured with a Cannon digital camera system (model: Power Shot S45).

\section{Results}

Comparison of $\mathrm{G}_{2} / \mathrm{M}$ arrest and cytotoxicity in $\mathrm{H} 460$ and A549. We first compared the change of cell cycle in two NSCLCs, H460 and A549, after exposing cells to $\gamma$-radiation. Results of typical experiments are shown in Fig. 1A and B. H460 cells showed a significant $\mathrm{G}_{2} / \mathrm{M}$ arrest after $12 \mathrm{~h}$ of irradiation, reaching up to $60 \%$ of $\mathrm{G}_{2} / \mathrm{M}$ phase arrest. A549 cells also showed a significant $\mathrm{G}_{2} / \mathrm{M}$ arrest after $12 \mathrm{~h}$ of exposure; however, this disappeared after $24 \mathrm{~h}$ of exposure. Moreover, irradiated H460 cells showed a significant cytotoxicity, unlike A549 cells that showed great tolerance to radiation at $10 \mathrm{~Gy}$ (Fig. 2A). This lower cell survival in H460 cells may come from cell detachment, because numerous floating cells (indicated by arrows) in the region of supernatant appeared in the irradiated H460 cells (Fig. 2B). In contrast, no floating cells were seen in the irradiated A549 cells. 
A)
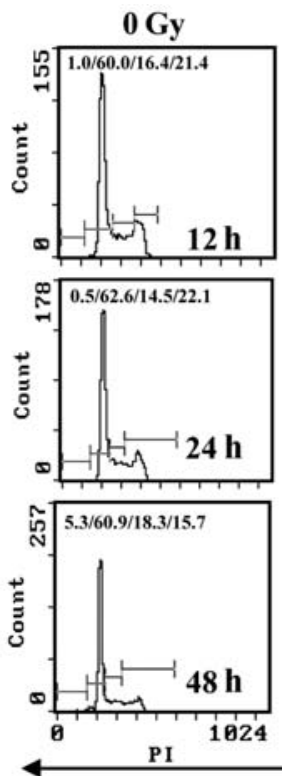

B)
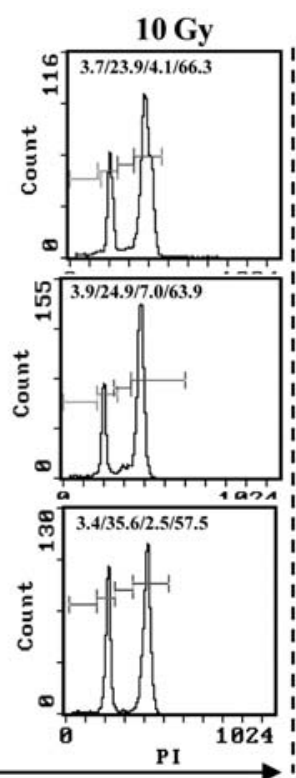

H460
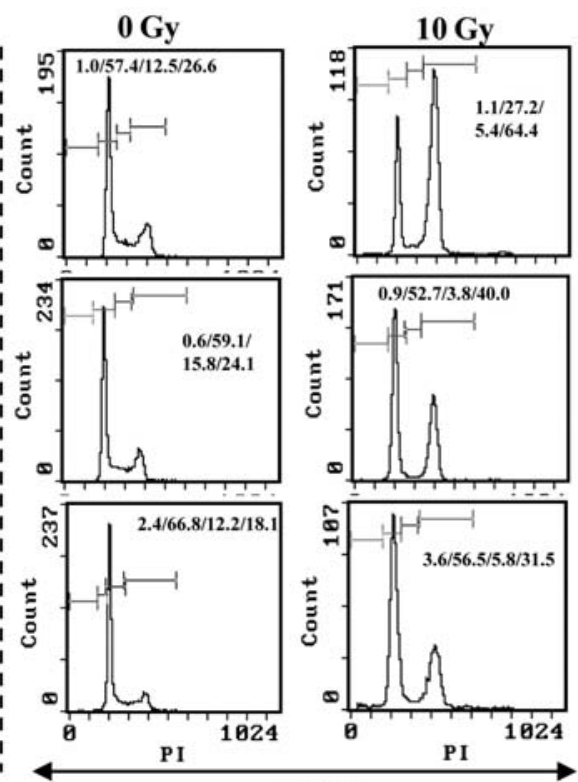

A549

$24 \mathrm{~h}$ after irradiation

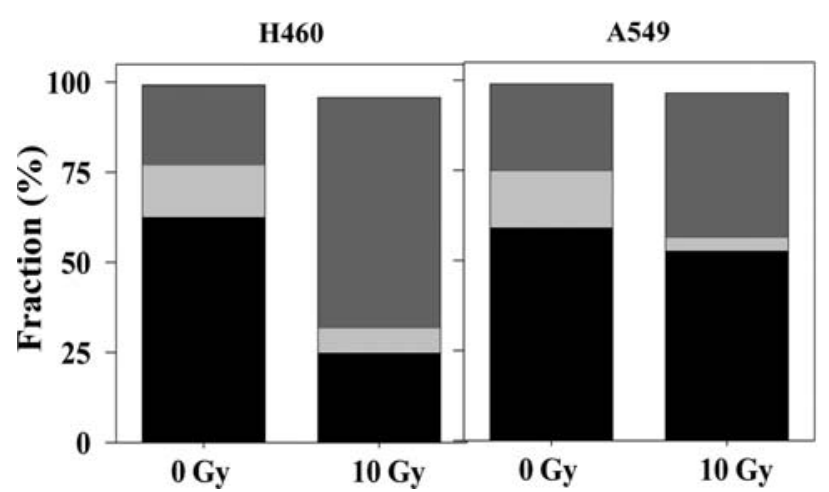

$48 \mathrm{~h}$ after irradiation

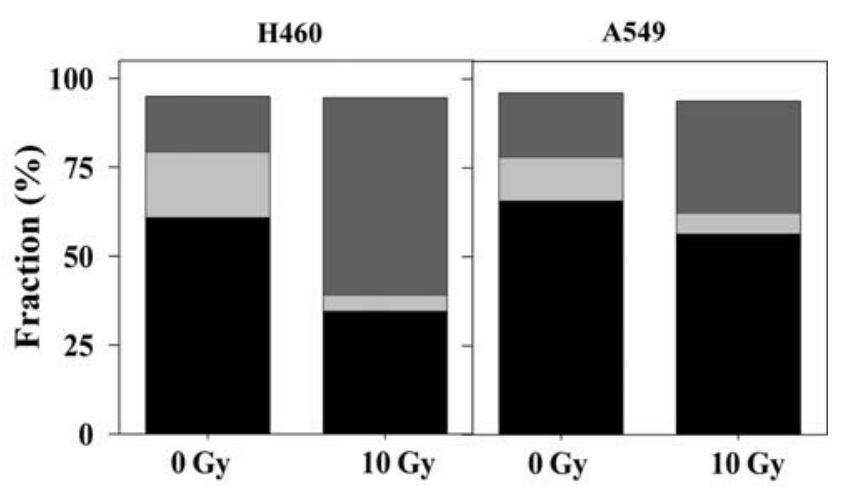

Figure 1. Induction of $\mathrm{G}_{2} / \mathrm{M}$ arrest in $\mathrm{H} 460$ by irradiation. (A) FAScan analysis in $\mathrm{H} 460$ and A549. (B) Comparison of each cell cycle fraction in H460 and A549. Dark gray, $\mathrm{G}_{2} / \mathrm{M}$ phase; bright gray, $\mathrm{S}$ phase; black, $\mathrm{G} 1$ phase.

Analysis of methylation in the region of $\mathrm{CpG}$ islands in $\mathrm{H} 460$ and A549. As previously noted, PTEN is correlated with tumor radioresistance in certain cancer cells. Thus, we investigated whether PTEN participates in the signaling pathway for radioresistance in the two NSCLCs. We used the bisulfite pyrosequencing method for methylation analyses of the PTEN gene. Each primer was designed using PSQ assay design program (Biotage), and the sequences of primers are listed in Fig. 3A. We selected five CpG sites (positions 1-5) as shown in Fig. 3A, and bisulfite-modified gDNA was prepared using EZ DNA Methylation-Gold kit (Zymo Research) as noted in Materials and methods, in which the Y sequence (depicted as boxes) means the methylated sited in H460 and A549 through positions 1-5. After conducting PCR amplification, the methylation percentage was calculated by averaging the degree of methylation at $5 \mathrm{CpG}$ sites formulated in pyrosequencing (Fig. 3B). As shown in Fig. 3C, the higher methylated CpG sites in all the positions tested were detected in A549 cells rather than in $\mathrm{H} 460$ cells, and the average of the extent of the methylation was 4.3 times higher in A549 cells than in H460 cells. We also confirmed the expression level of PTEN in
H460 and A549 cells by RT-PCR analysis. As shown in Fig. 3D, PTEN was highly expressed in H460, but not in A549 cells.

Determination of the signaling pathways involved in radioresponse. A signaling pathway for PTEN through p53 has been established. We investigated whether the pathway would be associated with the differences in radioresistance in both NSCLCs. As expected, PTEN acts as a negative regulator for pAkt, and the pAkt acts as a negative regulator for p53 expression (Fig. 4). We concluded that the radiosensitivity shown in H460 cells may be due to the PTEN expression through p53 signaling pathway.

\section{Discussion}

The combination of modalities for cancer treatment offers improvements in the survival of patients compared with individual therapeutic approaches (32). These therapeutic benefits have been achieved with combinations of chemotherapy and radiotherapy in a variety of cancers (32). The 
A)
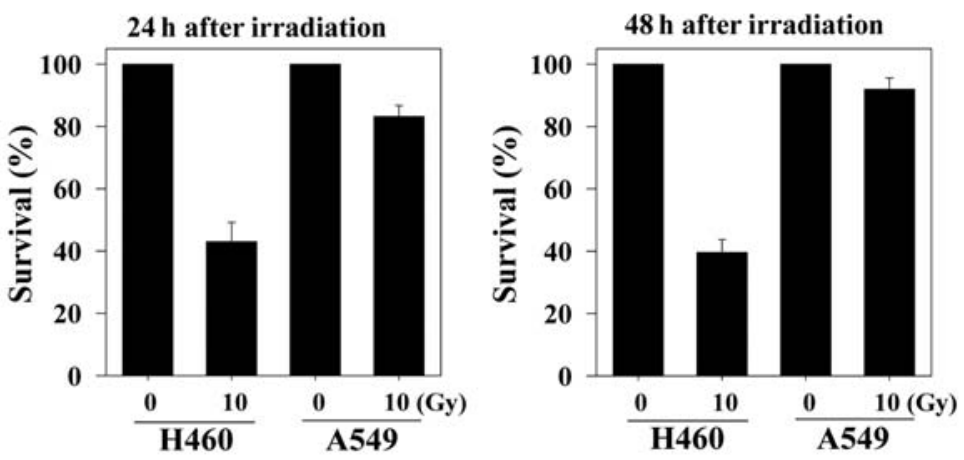

B)

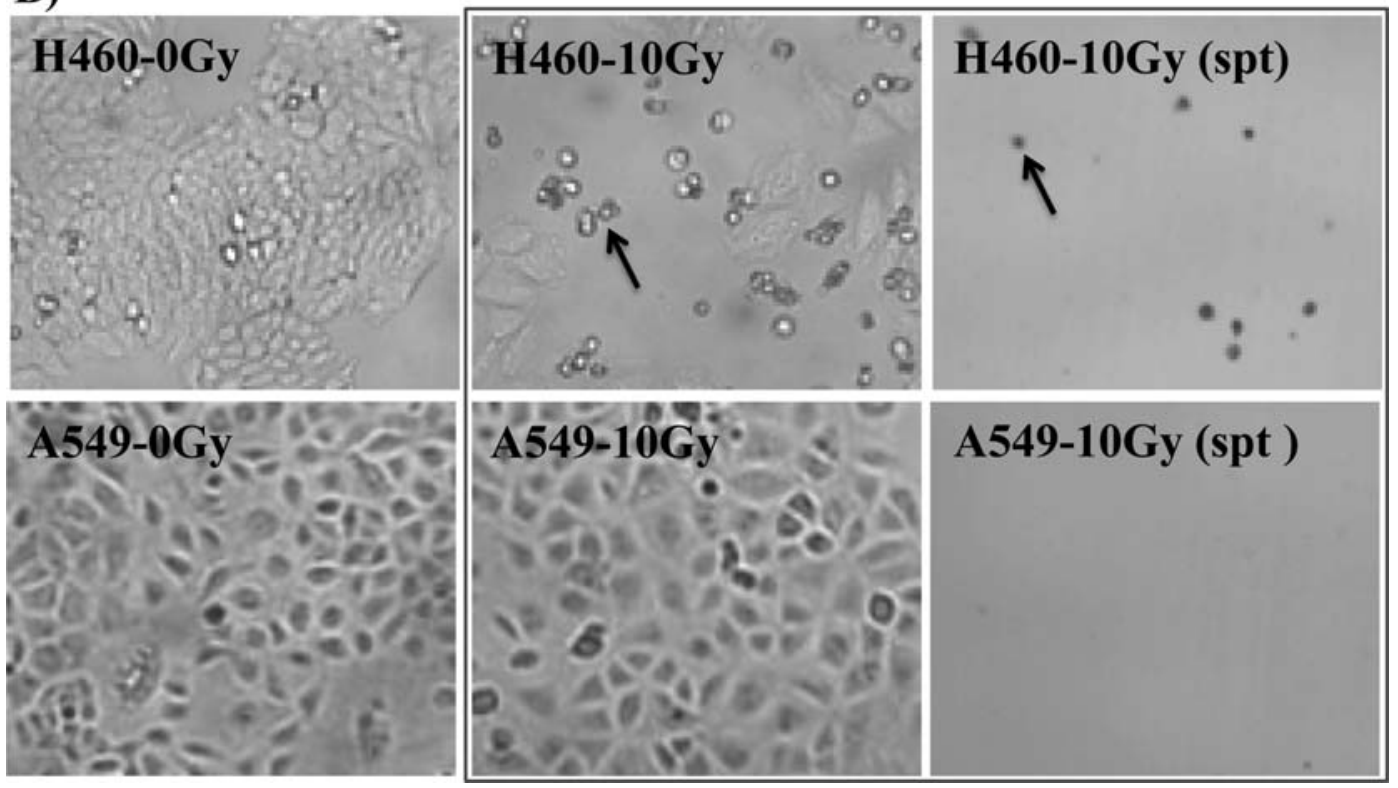

Figure 2. Comparison of cell cytotoxicity. (A) Comparison of surviving fractions after irradiation in H460 and A549 cells. (B) Microscopic views after irradiation. Cells after irradiation were harvested and resuspended in PBS. Floating cells from both total cell culture and the supernatant (spt) were photographed and are indicated by arrows.

cytotoxicity of most chemotherapeutic agents as well as that of radiation is highly dependent on the phase of the cell cycle; for example, the ability of anti-microtubule agents to block cell cycle progression in the $\mathrm{G}_{2} / \mathrm{M}$ phase is the biologic basis for combination of these agents with radiation $(32,33)$. The $\mathrm{G}_{2} / \mathrm{M}$ phase is the one most sensitive to ionizing radiation; thus, many research efforts have focused on the combination of radiotherapy methods that arrest cells in the $\mathrm{G}_{2} / \mathrm{M}$ phase by using specific chemicals and then irradiating the cells to increase the radiosensitivity potential $(11-13,34,35)$. However, although differences in radioresponse between various small cell lung cancers (SCLCs) and NSCLCs are known (29), little has been determined between different NSCLCs.

One factor known to increase tumor cell resistance to radiation, the importance of $\mathrm{PI} 3 \mathrm{~K} / \mathrm{AKT}$ targeting for overcoming resistance of tumors to radiotherapy, has been tested in vitro and in vivo and the results indicate this cascade is a promising target (24-26). The activation of Akt plays a critical role in fundamental cellular functions such as cell proliferation and survival by phosphorylation of a variety of substrates (36-38). Constitutively active Akt results in augmented resistance against apoptotic cellular insults, such as growth factor deprivation, UV irradiation, or loss of matrix attachment (39). Akt activation is found in many types of human tumors including breast cancer, lung cancer, melanoma, and leukemia $(40,41)$.

Human p53 is a 393-amino acid nuclear protein that acts biochemically as a transcription factor and biologically as a tumor suppressor (42). As a key regulator of cell growth and cell death, p53 is activated by many environmental stimuli, including DNA-damaging agents. Activated p53 acts as a guardian of the genome by inducing growth arrest to allow cells to repair the damage or apoptosis if the damage is too severe and irreparable $(43,44)$. Thus, it is no surprise that $\mathrm{p} 53$ is frequently inactivated via multiple mechanisms during human carcinogenesis. The most common mechanism is the point mutation at the $p 53$ gene, which occurs in $50 \%$ of human 
A)

\begin{tabular}{|c|c|c|c|c|c|c|}
\hline \multicolumn{7}{|c|}{ Original sequences } \\
\hline GTTTGGATGT & GGGTGCTTGT & GTAACCAGTT & CCCCAAGCGC & CAGCCCCGAC & AGCGCTCCTT & GGGAGGCTG \\
\hline GTCCGAGCCC & CTGTTTCCGC & CGCGGCGCAG & GAAGGGTTGG & GGTTCCGCTG & CCTGCACCAG & CAAGAGCAC \\
\hline CCCGAGCAAA & GGAAGAAGAC & GACTTGCCTC & CGGAGCTATC & ACTGGGGAGT & GGGAATTTGG & \\
\hline \multicolumn{7}{|c|}{ Bisulfite converted sequences } \\
\hline GTTTGGATGT & GGGTGTTTGT & GTAATTAGTT & TTTTAACQGT & 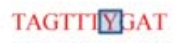 & ACचGттттт & \GGGAGGTTG \\
\hline GTQGAGTTT & TTGTTTTYGT & YGYGGYGTAG & GAAGGGTTGG & GGTTTYGTTG & TTTGTATTAG & GTAAGAGTAT \\
\hline TTYGAGTAAA & GGAAGAAGAY & GATTTGTTTT & YGGAGTTATT & ATTGGGGAGT & GGGAATTTGG & \\
\hline
\end{tabular}

PTEN Forward primer : 5'-GGATGTGGGTGTTTGTGTAATTA-3' PTEN Reverse primer : 5'-AATTCCCACTCCCCAATAATAAC-3' PTEN Sequencing primer : 5 '-TTTGTGTAATTAGTTTTTTA-3, PTEN Sequence to analyze : AGYGT TAGTTTYGAT AGYGTTTTTT YGGGAGGTTG GTTYG Y: methylated position in $\mathrm{H} 460$ and/or A549 (position 1 to 5)

B)
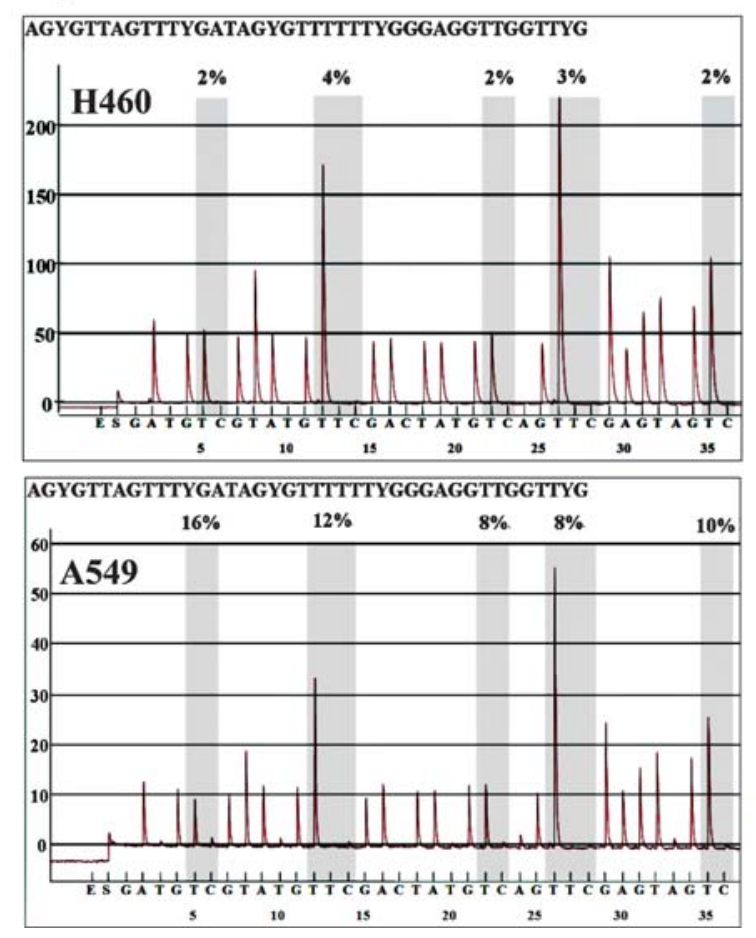

C)
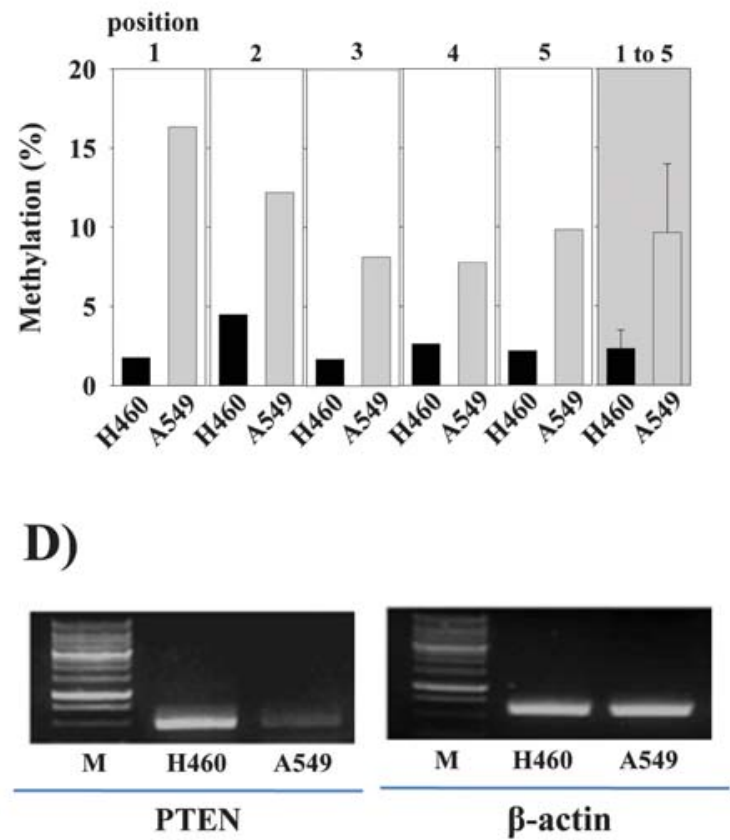

Figure 3. Pyrosequencing of $5 \mathrm{CpG}$ islands on PTEN. (A) Original sequence of PTEN and bisulfite-converted sequences. Each Y shown in red sequences indicates the methylated position in both cell lines. (B) Diagram of pyrosequencing. Each colored box indicates the position of the five Ys shown in panel A. (C) Comparison of fractions in the methylated CpG positions. The last bars indicate the means of all the methylated positions, 1-6. (D) RT-PCR analysis of PTEN genes in H460 and A549 cells.

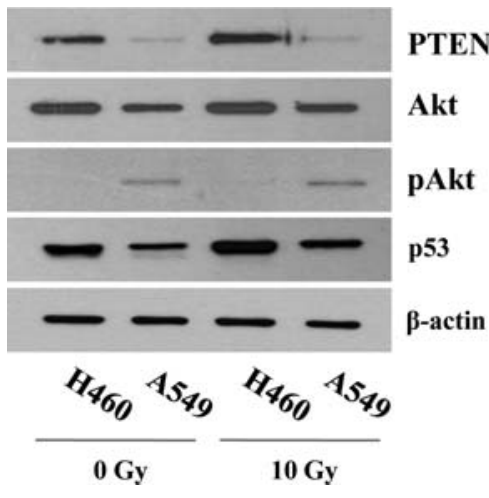

Figure 4. Western blot analysis. Cells were grown for $48 \mathrm{~h}$ after irradiation and harvested. cancers (45). Moreover, in certain cancer cells that bear wildtype p53, p53 is often inactivated by a variety of mechanisms. One common mechanism is Mdm2-mediated p53 binding, ubiquitination, and degradation (46). As noted above, p53 status and cancer radiosensitivity have been widely studied. Loss of p53 function, as in p53 mutation, increases resistance to radiation in many human cancers $(7-13,34,47)$.

In this study, we found that the A549 cells were more resistant compared to $\mathrm{H} 460$ cells. We also found that $\mathrm{p} 53$ expression was increased by radiation, meaning that cells encountered severe stress due to irradiation. However, approaches to endure the stress were somewhat different in the two NSCLCs. The extent of p53 induction was lower in A549 than in H460 and this difference in p53 induction by irradiation must be the determinant for the radiosensitivity in 
both lung cancer cell types. The decreased expression level of p53 in A549 compared to in H460 must come from the higher induction of pAkt in A549 than in H460 according to the Western blot experiments. Pyrosequencing has been widely used for determining the content of the methylated $\mathrm{CpG}$ island in many genes with a high GC rate. Thus, we compared the extent of methylation between two PTEN genes, known to be negative regulators of pAkt, existing in two cancer cell types. As expected, all the selected $5 \mathrm{CpG}$ positions in PTEN were more methylated in A549, and we concluded that the transcriptional expression of the PTEN gene in A549 was lower than in H460. In conclusion, the radioresistance that has been shown in A549, results from the highly methylated PTEN.

\section{Acknowledgements}

This work was supported by the Nuclear Research and Development Program from the Ministry of Education, Science and Technology (MEST) of Republic of Korea.

\section{References}

1. Jemal A, Siegel R, Ward E, et al: Cancer statistics. CA Cancer J Clin 57: 43-66, 2007.

2. Parker SL, Tong T, Bolden S and Wingo PA: Cancer statistics. CA Cancer J Clin 47: 5-27, 1997.

3. Parkin DM, Bray F, Ferlay J and Pisani P: Global cancer statistics, 2002. CA Cancer J Clin 55: 74-108, 2005.

4. Dy GK and Adjei AA: Novel targets for lung cancer therapy. Part I. J Clin Oncol 20: 2881-2894, 2002.

5. Dy GK and Adjei AA: Novel targets for lung cancer therapy. Part II. J Clin Oncol 20: 3016-3028, 2002.

6. Fu XY, Zhang SW, Ran RQ, Shen ZH, Gu JX and Cao SL: Restoration of the p16 gene is related to increased radiosensitivity of p16-deficient lung adenocarcinoma cell lines. J Cancer Res Clin Oncol 124: 621-626, 1998.

7. O'Connor PM, Jackman J, Jondle D, Bhatia K, Magrath I and Kohn K: Role of the p53 tumor suppressor gene in cell cycle arrest and radiosensitivity of Burkitt's lymphoma cell lines. Cancer Res 53: 4776-4780, 1993

8. Hamada M, Fujiwara T, Hizuta A, Gochi A, Naomoto Y, Takakura N, Takahashi K, Roth JA, Tanaka N and Orita K: The p53 gene is a potent determinant of chemosensitivity and radiosensitivity in gastric and colorectal cancers. J Cancer Res Clin Oncol 122: 360-365, 1996.

9. Fan S, EL-Deiry WS, Bae I, Freeman J, Jondle D, Bhatia K, Fornace AJ, Magrath I, Kohn KW and O'Connor P: p53 gene mutations are associated with decreased sensitivity of human lymphoma cells to DNA damaging agents. Cancer Res 54: 5824-5830, 1994.

10. Mcilwrath AJ, Vasey PA, Ross GM and Brown R: Cell cycle arrests and radiosensitivity of human tumor cell lines: dependence on wild-type p53 for radiosensitivity. Cancer Res 54: 3718-3722, 1994.

11. Miyakoshi J, Yamagishi N, Ohtsu S and Takebe H: Changes in radiation sensitivity of human osteosarcoma cells after p53 introduction. Jpn J Cancer Res 86: 711-713, 1995.

12. Siles E, Villalobos M, Valenzuela MT, Nunez MI, Gordon A, McMillan TJ, Pedraza V and Almodovar JMR: Relationship between p53 status and radiosensitivity in human tumor cell lines. Br J Cancer 73: 581-588, 1996.

13. Gallardo D, Drazan KE and McBride WH: Adenovirus-based transfer of wild type p53 gene increases ovarian tumor radiosensitivity. Cancer Res 56: 4891-4893, 1996.

14. FitzGerald TJ, Henault S, Sakakeeny M, Santucci MA, Pierce JH, Anklesaria P, Kase K, Das I and Greenberger JS: Expression of transfected recombinant oncogenes increases radiation resistance of clonal hematopoietic and fibroblast cell lines selectively at a clinical low dose rate. Radiat Res 122: 44-52, 1990.

15. McKenna WG, Weiss MC, Endlich B, Ling CC, Bakanauskas V, Kelsten ML and Muschel RJ: Synergistic effect of the v-myc oncogene with H-ras on radioresistance. Cancer Res 50: 97-102, 1990 .
16. McKenna WG, Iliakis G, Weiss MC, Bernhard EJ and Muschel RJ: Increased G2 delay in radiation-resistant cells obtained by transformation of primary rat embryo cells with the oncogenes H-ras and v-myc. Radiat Res 125: 283-287, 1991.

17. Ling CC and Endlich B: Radioresistance induced by oncogenic transformation. Radiat Res 120: 267-279, 1989.

18. Pomp J, Ouwerkerk IJM, Hermans J, Wondergem J, Cornelisse CJ, Leer JW and Schrier P: The influence of the oncogenes NRAS and MYC on the radiation sensitivity of cells of a human melanoma cell line. Radiat Res 146: 374-381, 1996.

19. Kasid U, Pfeifer A, Weichselbaum RR, Dritschilo A and Mark G: The raf oncogene is associated with a radiation-resistant human laryngeal cancer. Science 237: 1039-1041, 1987.

20. Pirollo KF, Garner R, Yuan SY, Li L, Blattner WA and Chang EH: Raf involvement in the simultaneous genetic transfer of the radioresistant and transforming phenotypes. Int J Radiat Biol 55: 783-796, 1989.

21. Stuschke M, Sak A, Wurm R, Sinn B, Wolf G, Stüben G and Budach V: Radiation-induced apoptosis in human non-smallcell lung cancer cell lines is secondary to cell-cycle progression beyond the G2-phase checkpoint. Int J Radiat Biol 78: 807-819, 2002.

22. Baumann M, Krause M, Zips D, et al: Molecular targeting in radiotherapy of lung cancer. Lung Cancer 45: S187-S197, 2004.

23. Shin YK, Park JS, Kim HS, Jun HJ, Kim GE, Suh CO, Yun YS and Pyo H: Radiosensitivity enhancement by celecoxib, a cyclooxygenase (COX)-2 selective inhibitor, via COX-2-dependent cell cycle regulation on human cancer cells expressing differential COX-2 levels. Cancer Res 65: 9501-9509, 2005.

24. Albert JM, Kim KW, Cao C and Lu B: Targeting the Akt/ mammalian target of rapamycin pathway for radiosensitization of breast cancer. Mol Cancer Ther 5: 1183-1189, 2006.

25. Nakamura JL, Karlsson A, Arvold ND, et al: PKB/Akt mediates radiosensitization by the signaling inhibitor LY294002 in human malignant gliomas. J Neurooncol 71: 215-222, 2005.

26. Lee CM, Fuhrman CB, Planelles V, et al: Phosphatidylinositol 3-kinase inhibition by LY294002 radiosensitizes human cervical cancer cell lines. Clin Cancer Res 12: 250-256, 2006.

27. Park JK, Jung HY, Park SH, Kang SY, Yi MR, Um HD and Hong SH: Combination of PTEN and gamma-ionizing radiation enhances cell death and $\mathrm{G}(2) / \mathrm{M}$ arrest through regulation of AKT activity and p21 induction in non-small-cell lung cancer cells. Int J Radiat Oncol Biol Phys 70: 1552-1560, 2008.

28. Hemstrom TH, Sandstrom M and Zhivotovsky B: Inhibitors of the PI3-kinase/Akt pathway induce mitotic catastrophe in nonsmall cell lung cancer cells. Int J Cancer 119: 1028-1038, 2006.

29. Das AK, Sato M, Story MD, et al: Non-small-cell lung cancers with kinase domain mutations in the epidermal growth factor receptor are sensitive to ionizing radiation. Cancer Res 66: 9601-9608, 2006

30. Baumann M, Krause M, Dikomey E, et al: EGFR-targeted anti-cancer drugs in radiotherapy: preclinical evaluation of mechanisms. Radiother Oncol 83: 238-248, 2007.

31. Krause M, Zips D, Thames HD, Kummermehr J and Baumann M: Preclinical evaluation of molecular-targeted anticancer agents for radiotherapy. Radiother Oncol 80: 112-122, 2006.

32. Akashi Y, Okamoto I, Suzuki M, Tamura K, Iwasa T, Hisada S, Satoh T, Nakagawa K, Ono K and Fukuoka M: The novel microtubule-interfering agent TZT-1027 enhances the anticancer effect of radiation in vitro and in vivo. Br J Cancer 96: 1532-1539, 2007.

33. Pawlik TM and Keyomarsi K: Role of cell cycle in mediating sensitivity to radiotherapy. Int J Radiat Oncol Biol Phys 59: 928-942, 2004.

34. Tsang NM, Nagasawa H, Li C and Little JB: Abrogation of p53 function by transfection of HPV 16 E6 gene enhances the resistance of human diploid fibroblasts to ionizing radiation. Oncogene 10: 2403-2408, 1995.

35. Nishizaki M, Meyn RE, Levy LB, Atkinson EN, White RA, Roth JA and Ji L: Synergistic inhibition of human lung cancer cell growth by adenovirus-mediated wild-type $p 53$ gene transfer in combination with docetaxel and radiation therapeutics in vitro and in vivo. Clin Cancer Res 7: 2887-2897, 2001.

36. Ohsaki Y, Tanno S, Fujita Y, et al: Epidermal growth factor receptor expression correlates with poor prognosis in non-small cell lung cancer patients with p53 overexpression. Oncol Rep 7: 603-607, 2000.

37. Brognard J, Clark AS, Ni Y and Dennis PA: Akt/protein kinase B is constitutively active in non-small cell lung cancer cells and promotes cellular survival and resistance to chemotherapy and radiation. Cancer Res 61: 3986-3997, 2001. 
38. Toulany M, Baumann M and Rodemann HP: Stimulated PI3KAKT signaling mediated through ligand or radiation-induced EGFR depends indirectly, but not directly, on constitutive K-Ras activity. Mol Cancer Res 5: 863-872, 2007.

39. Li B, Desai SA, MacCorkle-Chosnek RA, Fan L and Spencer DM: A novel conditional Akt survival 'switch' reversibly protects cells from apoptosis. Gene Ther 9: 233-244, 2002.

40. Fry MJ: Phosphoinositide 3-kinase signalling in breast cancer: how big a role might it play? Breast Cancer Res 3: 304-312, 2001

41. Lin X, Böhle AS, Dohrmann P, Leuschner I, Schulz A, Kremer B and Fändrich F: Overexpression of phosphatidylinositol 3-kinase in human lung cancer. Langenbecks Arch Surg 386: 293-301, 2001.

42. Vogelstein B, Lane D and Levine AJ: Surfing the p53 network Nature 408: 307-310, 2000.
43. Levine AJ: p53, the cellular gatekeeper for growth and division. Cell 88: 323-321, 1997.

44. Ko LJ and Prives C: p53: puzzle and paradigm. Genes Dev 10: 1054-1072, 1996.

45. Greenblatt MS, Bennett WP, Hollstein M, et al: Mutations in the p53 tumor suppressor gene: clues to cancer etiology and molecular pathogenesis. Cancer Res 54: 4855-4878, 1994.

46. Freedman DA and Levine AJ: Regulation of the p53 protein by the MDM2 oncoprotein - thirty-eighth G.H.A. Clowes Memorial Award Lecture. Cancer Res 59: 1-7, 1999.

47. Lücke-Huhle C: Alterations in oncogenic expression and radiosensitivity in the most frequently used SV40-transformed human skin fibroblasts. Int J Radiat Biol 65: 665-673, 1994. 